\title{
IMPLEMENTASI PEMBELAJARAN BAHASA JEPANG BERBASIS 4C DI SMK NEGERI 1 SINGARAJA
}

\author{
N.K.W.Dewi ${ }^{1}$ K.E.K.Adnyani ${ }^{2}$ D.M.S,Mardani ${ }^{3}$ \\ 123 Jurusan Pendidikan Bahasa Jepang, Universitas Pendidikan Ganesha, Singaraja,Bali \\ e-mail: komang.warsita.dewi@gmail.com \\ krishna.adnyani@undiksha.ac.id desak.mardani@undiksha.ac.id
}

\begin{abstract}
Abstrak
Penelitian ini bertujuan untuk menganalisis implementasi pembelajaran bahasa Jepang berbasis $4 \mathrm{C}$ di SMK Negeri 1 Singaraja dan kendala-kendala yang dihadapi guru serta cara mengatasi kendala tersebut. Penelitian ini merupakan penelitian deskriptif kualitatif. Subjek penelitian ini adalah guru bahasa Jepang SMK Negeri 1 Singaraja. Objek penelitian ini adalah implementasi pembelajaran bahasa Jepang berbasis 4C di SMK Negeri 1 Singaraja. Metode pengumpulan data yang digunakan adalah metode observasi dan wawancara. Hasil penelitian ini yaitu guru bahasa Jepang SMK Negeri 1 Singaraja telah menerapkan langkah-langkah pembelajaran berbasis 4C (critical thinking and problem solving, collaboraton, creativity and innovation dan communication) sesuai dengan teori, tetapi pada aspek creativity and innovation dan collaboration kurang berjalan dengan baik. Kendala yang dialami guru yaitu pada kegiatan creativity and innovation siswa masih kurang mampu dalam menciptakan ide-ide yang baru, dalam kegiatan collaboration siswa membahas hal yang tidak berkaitan dengan materi, serta kendala alokasi waktu, guru kekurangan waktu dalam melakukan proses pembelajaran, Solusi guru dalam mengatasi kendala pembelajaran berbasis $4 \mathrm{C}$ yaitu memberikan motivasi berupa penguatan verbal maupun non verbal, menginformasikan rencana kegiatan untuk pertemuan selanjutnya dan mencari informasi tambahan, lebih mendisiplinkan waktu serta memberi teguran kepada siswa yang ribut diluar konteks pembelajaran.
\end{abstract}

Kata kunci: implementasi, pembelajaran berbasis $4 \mathrm{C}$, creativity and innovation, collaboration.

\section{要旨}

本研究の目的は、シンガラジャ第一公立専門高等学校における4Cに基づく日本語授業の実施。ま た、教える時の問題と解決方法説明する。研究の対象は、シンガラジャ第一公立専門高等学校の日本 語教師である。研究の対象者はシンガラジャ第一公立専門高等学校における4Cに基づく日本語授業の 実施。データは、観察及びインタビューにより収集し定性的記述法により分析した。結果は、シンガ ラジャ第一公立専門高等学校の日本語授業において、結果は、日本語教師が理論にしたがっては4C、 批判的吟味、協働力、創造力を適用したが、まだ課題が残っていることが分かった。創造力ける点に おいて、学習者は未だに新しい意見を生み出すことが出来なかった。また、協働力にて、学生は文書 に関係のない事項について話し合うや授業の時間割不足が取り上げられる。その問題解決法は、4Cに 基づく日本語授業にて、日本語教師は、学習者にモティベーションを与えたり、応援をしたり、次回 授業の内容を知らせて用意させたり、学習者が時間を守るように注意したりした。

キーワード : 実施、4Cに基づく授業, 創造力，協働力 


\section{Pendahuluan}

Perubahan paradigma pembelajaran baru menuntut siswa memiliki keterampilan untuk berpikir lebih tinggi yang sangat diperlukan dalam mempersiapkan peserta didik dalam menghadapi tantangan global. Pendidikan menjadi semakin penting untuk menjamin siswa memiliki keterampilan belajar dan berinovasi, keterampilan menggunakan teknologi dan media informasi, serta dapat bekerja, dan mampu bertahan dengan menggunakan berbagai keterampilan untuk hidup.

Untuk menjawab tantangan dan harapan tersebut dapat diwujudkan melalui suatu pendidikan yang memfasilitasi peserta didik untuk dapat mengembangkan potensi yang dimilikinya. Kegiatan pembelajaran di sekolah harus merujuk pada 4 karakter belajar abad 21 yang biasanya dirumuskan dalam 4C.

Pembelajaran berbasis 4C merupakan pembelajaran yang menuntut siswa memiliki kemampuan berpikir kritis dan pemecahan masalah (Critical-Thinking and Problem-Solving Skills), kemampuan berkomunikasi (Communication Skills), Kemampuan bekerjasama (Collaboration Skills), dan kemampuan mencipta dan membaharui (Creativity and Innovation Skills) Frydenberg \& Andone (dalam Wijaya, dkk, 2016).

Dalam penerapannya langkah-langkah pembelajaran berbasis $4 \mathrm{C}$ tidak dapat diklasifikasikan secara terpisah, karena pembelajaran 4C saling berhubungan dan berkaitan antara aspek yang satu dengan aspek yang lainnya.

Dalam melaksanakan pembelajaran berbasis 4C guru harus pandai dalam menggunakan kreativitasnya dalam memvariasikan pembelajaran secara arif dan bijaksana. Pembelajaran berbasis 4C merupakan proses pembelajaran yang berbeda dengan proses pembelajaran pada kurikulum sebelumnya, pembelajaran berbasis $4 \mathrm{C}$ mengharapkan siswa untuk mampu berpikir kritis, kreatif, kolaborasi dan mampu berkomunikasi dengan baik. Guru diharapkan mampu menentukan metode pembelajaran yang cocok agar dalam proses pembelajaran siswa lebih aktif dan kreatif.

SMK Negeri 1 Singaraja memiliki program pembelajaran yang sudah direncanakan dan dilaksanakan dengan baik dan sudah menerapkan pembelajaran berbasis $4 \mathrm{C}$ dalam proses pembelajaran. Berdasarkan wawancara awal pada tanggal 8 April 2019 hasil wawancara yang dilakukan dengan guru mata pelajaran bahasa Jepang diperoleh informasi bahwa SMK Negeri 1 Singaraja merupakan sekolah kejuruan yang sudah terakreditasi A dan merupakan sekolah dengan siswa yang berprestasi dalam bidang akademik maupun non akadamik. Setiap tahun, SMK Negeri 1 Singaraja mengirim siswa-siswi untuk mengikuti berbagai perlombaan di bidang bahasa Jepang yang diadakan oleh lembaga-lembaga pemerintahan ataupun universitas-universitas yang ada di bali. Namun selama proses belajar mengajar beliau masih mengalami kendala dalam menerapkan pembelajaran berbasis $4 \mathrm{C}$. Sehingga dengan demikian diperlukannya penelitian tentang bagaimana implementasi pembelajaran berbasis $4 \mathrm{C}$ secara keseluruhan.

Penelitian sejenis dilakukan oleh Diantari (2017) dengan mengangkat tema implementasi pembelajaran dengan pendekatan saintifik oleh guru bahasa Jepang di SMA Pariwisata Saraswati Klungkung. Penelitian ini merupakan penelitian deskriptif kualitatif, menjelaskan tentang implementasi pembelajaran berbasis saintifik dan kendala yang dihadapi oleh guru secara menyeluruh. Hasil dalam penelitian menunjukkan bahwa pengimplementasian aspek $5 \mathrm{M}$ secara umum dapat diterapkan secara utuh, tetapi dalam aspek menanya kurang berjalan dengan baik karena siswa kurang percaya diri.

Penelitian lain yang juga sejenis yaitu penelitian yang dilakukan oleh Mukhlis (2018). Penelitian ini tentang analisis kemampuan berpikir kritis siswa dalam menyelesaikan masalah deret aritmatika dimensi dua berdasarkan keterampilan 4c-p21. Dalam penelitian ini dijelaskan bahwa keterampilan berpikir kritis memiliki peranan yang sangat penting bagi siswa dalam mengkonstruk kemampuan siswa dan menemukan alternatif terbaik dalam mememecahkan masalah.

Berdasarkan permasalahan yang telah dipaparkan, maka rumusan masalah dari penelitian ini adalah bagaimanakah implementasi pembelajaran bahasa Jepang berbasis 4C di SMK Negeri 1 Singaraja.. Penelitian ini bertujuan untuk mendeskripsikan (1) bagaimanakah implementasi pembelajaran bahasa Jepang berbasis 4C di SMK Negeri 1 Singaraja. (2) 
apakah kendala ang dialami guru selama mengimlementasikan pembelajaran bahasa Jepang berbasis $4 \mathrm{C}$ serta (3) bagaimanakah solusi dalam mengatasi kendala tersebut.

\section{Metode}

\section{Metode Pengumpulan Data}

Penelitian ini merupakan penelitian deskriptif kualitatif mengenai implementasi pembelajaran bahasa Jepang berbasis 4C di SMK Negeri 1 Singaraja.. Penelitian ini menggunakan metode deskriptif kualitatif karena bertujuan untuk mendeskripsikan data dalam bentuk kalimat secara rinci mengenai bagaimanakah implementasi pembelajaran bahasa Jepang berbasis 4C di SMK Negeri 1 Singaraja.berdasarkan fakta-fakta yang diperoleh melalui observasi dan wawancara. Metode pengumpulan data dalam penelitian ini yaitu menggunakan metode observasi dan wawancara. Jenis observasi yang dilakukan yaitu observasi non partisipan yang dilaksanakan saat proses pembelajaran berlangsung di kelas. Pengamatan dan pencatatan dalam lembar observasi dilakukan selama proses pembelajaran berlangsung di kelas. Observasi dilakukan sebanyak enam kali di kelas $X$ UPW A dan UPW B. Sedangkan metode wawancara dilaksanakan dua kali yaitu sebelum observasi dan wawancara yang dilaksanakan setelah observasi.

Wawancara pertama dilaksanakan pada tanggal 8 April 2019 dengan menggunakan metode wawancara semi terstruktur. Wawancara ini bertujuan sebagai pengetahuan dasar untuk melakukan penelitian tentang bagaimana penerapan pembelajaran berbasis $4 \mathrm{C}$ di SMK Negeri 1 Singaraja. Wawancara kedua dilakukan pada tanggal 9 Mei 2019, dengan mengunakan metode wawancara semi terstruktur. Wawancara yang dilakukan bertujuan untuk menguatkan hasil observasi, melakukan klarifikasi penemuan data yang didapatkan pada saat observasi dan untuk mengetahui kendala-kendalayang dialami guru bahasa Jepang dalam menerapkan pembelajaran berbasis 4C di SMK Negeri 1 Singaraja.serta bagaimana solusi dari kendala tersebut. Sumber data dalam penelitian ini yaitu berupa data yang didapat dari hasil observasi dan wawancara yang dilakukan terhadap subjek penelitian. Subjek penelitian ini adalah guru bahasa Jepang di SMK Negeri 1 Singaraja yang berjumlah satu orang. Data yang diperoleh dari hasil observasi dan wawancara. Data yang didapatkan kemudian dianalisis dan dideskripsikan secara kualitatif, yaitu mendeskripsikan lewat uraian dan penjelasan. Langkah-langkah teknik analisis data yang digunakan yaitu Reduksi Data, Penyajian Data, dan Penarikan Kesimpulan.

Reduksi Data merupakan proses pemilihan, penyederhanaan, dan peringkasan data mentah yang berhasil dikumpulkan selama fase pengumpulan data dan memfokuskan pada hal-hal yang penting. Dalam penelitian ini, reduksi data akan dilakukan dengan penyederhanaan data yang diperoleh dari hasil observasi dan dokumentasi di SMK Negeri 1 Singaraja dan wawancara terhadap guru. Melalui proses reduksi ini maka memungkinkan melakukan pemilihan, pemusatan, pembuangan data yang tidak perlu, dan pengaturan data.

Penyajian Data dalam penelitian ini digunakan untuk memudahkan dalam memahami data, menganalisis dan menarik kesimpulan. Data yang didapatkan dari hasil observasi dan wawancara yang dilakukan dengan guru bahasa Jepang kemudian disusun dan dikelompokkan berdasarkan kategori-kategori tertentu sesuai dengan tujan penelitian.

Penarikan Kesimpulan dalam penelitian ini dilakukan apabila semua data telah terkumpul dan tersusun berdasarkan kategori-kategori tertentu kemudian menarik kesimpulan yang merupakan jawaban dari masalah penelitian. Penarikan kesimpulan disesuaikan dengan temuan atau keadaan di lapangan yang berkaitan dengan implementasi pembelajaran bahasa Jepang berbasis $4 \mathrm{C}$.

\section{Hasil dan Pembahasan}

\section{A. Hasil Penelitian}

\section{Hasil Observasi Pertama}

Observasi pertama dilakukan pada hari Jumat, 12 April di kelas X UPW B pada jam pelajaran 4-5. Materi yang disampaikan pada observasi pertama yaitu nanji desuka. Siswa 
diminta untuk mengamati dan mengidentifikasi kosakata baru yang terdapat di buku ajar. Kemudian guru memberikan contoh pengucapan kosakata dalam bahasa Jepang yang benar dan siswa bersama-sama mengikuti cara pengucapan guru. Pengajar menunjuk siswa secara acak, dan siswa tersebut diberikan kosa kata untuk menyebutkan bahasa Jepang serta artinya.

Guru kemudian menginstruksikan siswa untuk membentuk kelompok, siswa dibagi menjadi beberapa kelompok yang terdiri dari 3-4 orang dan memberikan sebuah wacana, siswa diharapkan mendiskusikan bersama teman kelompoknya untuk mencari pola kalimat, kosa kata baru serta makna dari wacana tersebut. Masing-masing kelompok mempresentasikan hasil diskusinya terkait isi wacana yang dibaca. Guru menuliskan pola kalimat serta kosa kata yang ditemukan siswa di papan tulis, dan menjelaskanya serta memberikan contoh.

Guru kemudian meminta siswa untuk membuat contoh kalimat baru yang sesuai dengan pola kalimat yang sebelumnya dipelajari, siswa diperbolehkan mencari informasi tambahan dari kamus, buku panduan maupun sumber lain. Siswa kemudian mengembangkan gagasan-gasan baru yang didapatkan. Siswa juga disuruh untuk membandingkan makna dari kalimat yang dibuat sendiri dengan kalimat yang dibuat oleh temannya.

Guru memberikan kesempatan kepada siswa untuk bertanya tentang materi yang belum dipahami, kemudian menyuruh siswa untuk melakukan percakapan singkat dengan teman sebangkunya untuk mengecek pemahaman siswa. Bersama kelompoknya siswa juga diminta membuat karangan singkat tentang waktu yang diperlukan dalam kegiatan mulai dari pukul berapa sampai pukul berapa bangun pagi, makan pagi, mandi, berangkat ke sekolah, pulang ke rumah, dan belajar. Siswa dituntut untuk berinovasi dengan menggunakan pemikiran yang kreatif dalam menggunakan kosa kata yang sudah diketahui ataupun kosa kata yang baru. Siswa mengecek kembali dan membandingkan kosakata dan pola kalimat yang ada di buku dengan kalimat yang telah dibuat.

Guru mempersilahkan kelompok yang sudah siap dan selesai membuat karangan singkat untuk membacakan hasil kerjanya, hasil dibacakan bergantian. Kelompok yang lain menyimak hasil karangan yang dibacakan, guru mempersilahkan kelompok lain untuk bertanya dan apabila terdapat pola kalimat yang tidak sesuai diperbolehkan untuk mengangkat tangan dan memperbaiki pola kalimat yang salah dan memberikan nilai tambahan kepada siswa yang mampu memperbaiki kesalahan temannya. Guru kemudian bertanya untuk memastikan pemahaman siswa, dan meminta siswa untuk menyimpulkan mengenai materi yang telah diajarkan.

\section{Hasil Observasi Kedua}

Observasi kedua dilakukan pada hari Selasa, 16 April di kelas X UPW A pada jam pelajaran 1-2. Materi yang disampaikan pada observasi pertama yaitu nanji desuka. Siswa kemudian diminta untuk mengamati dan mengidentifikasi kosa kata yang ada di buku, dan meminta siswa untuk menuliskan kosakata yang mereka ketahui di papan tulis. Kosakata ditulis dengan menggunakan huruf hiragana dan diterjemahkan kedalam bahasa Indonesia. Guru mengecek dan mengoreksi kosakata yang ditulis siswa dan menuliskan kosakata yang telah dikoreksi, guru memberikan contoh pengucapan kosakata dalam bahasa Jepang yang benar dan siswa berlatih menyebutkan kosa kata dengan benar.

Guru mengarahkan siswa untuk duduk sesuai kelompok dan memberikan sebuah wacana, siswa diharapkan mendiskusikan bersama kelompoknya untuk mencari pola kalimat, kosa kata serta makna dari wacana tersebut. Masing-masing kelompok mempresentasikan hasil diskusinya terkait isi wacana yang dibaca. Guru menuliskan pola kalimat yang ditemukan siswa di papan tulis, dan mengklarifikasi penemuan siswa serta memberikan sebuah contoh. Guru memberikan kesempatan kepada siswa untuk mengajukan pertanyaan.

Siswa kemudian membuat kalimat baru yang sesuai dengan pola kalimat yang sebelumnya dipelajari, Setelah itu siswa akan membandingkan kalimat yang dibuat dengan kalimat temannya. 
Guru melakukan drill dengan menuliskan kosa kata dan kalimat dalam bahasa Indonesia di papan tulis kemudian siswa menyebutkan bahasa Jepang dari kosa kata dan kalimat yang ditulis oleh guru. dan meminta siswa untuk melakukan wawancara dengan teman sebangkunya.

Siswa membuat karangan singkat tentang waktu yang diperlukan dalam kegiatan mulai dari pukul berapa sampai pukul berapa bangun pagi, makan pagi, mandi, berangkat ke sekolah, pulang ke rumah, dan belajar. siswa dituntut untuk berinovasi dengan menggunakan pemikiran yang kreatif, kemudian menyampaikan hasil karangannya, secara bergantian. Kelompok yang belum mendapat giliran, menyimak karangan temannya. Siswa diperkenankan untuk bertanya dan jika ada hasil karangan siswa yang pola kalimatnya salah, diperbolehkan untuk mengoreksi. Guru akan memberikan nilai tambahan kepada siswa yang mampu mengoreksi hasil karangan temannya. Setelah menyampaikan hasil diskusi. siswa membuat kesimpulan terkait pola kalimat yang dipelajari.

\section{Hasil Observasi Ketiga}

Observasi ketiga dilakukan pada hari Rabu, 17 April di kelas X UPW B pada jam pelajaran 1-2. Materi yang disampaikan pada observasi ketiga yaitu Toshositsu de hon 0 yomimasu. Guru kemudian menginstruksikan siswa untuk melihat dan mengamati gambar yang ada di powerpoint, kemudian siswa mengidentifikasi dan mencari tahu arti dari kosa kata yang diberikan oleh guru, guru kemudian mengucapkan contoh kosakata dalam bahasa Jepang. Siswa mengulang apa yang diucapkan guru sesuai dengan pelafalan yang benar.

Guru melakukan drill terhadap siswa dengan menampilkan gambar di powerpoint, lalu siswa menyebutkan bahasa Jepangnya. Setelah itu guru memanggil salah satu siswa untuk menyebutkan bahasa Indonesia dari kosa kata tersebut. Setelah kosakata disampaikan dengan baik, guru kemudian menginstruksikan siswa untuk duduk sesuai dengan kelompok masing-masing. Guru memberikan wacana bahasa Jepang, siswa kemudian diminta berdiskusi untuk mencari pola kalimat, kosa kata dan makna dari kalimat yang dibuat oleh guru. Guru kemudian menuliskan pola kalimat yang disebutkan siswa di papan tulis serta menjelaskan kembali jawaban dari siswa.

Guru kemudian meminta siswa untuk membuat contoh kalimat baru yang sesuai dengan pola kalimat yang dipelajari. Siswa yang belum berkesempatan untuk menyampaikan kalimat yang telah dibuat, ditunjuk untuk menebak makna dari kalimat yang telah disampaikan oleh siswa yang lain. Guru kemudian meminta siswa melakukan wawancara. Siswa mengecek kembali dan membandingkan kosakata dan pola kalimat yang sudah dipelajari dengan hasil wawancara yang telah dibuat. Jika terdapat perbedaan, guru memperbolehkan siswa untuk bertanya dan berdiskusi dengan anggota kelompoknya. Wawancara dilakukan secara bergantian, apabila terdapat pola kalimat yang tidak sesuai diperbolehkan untuk mengangkat tangan dan memperbaiki pola kalimat yang salah. Setelah siswa menyampaikan hasil wawancaranya guru kemudian meminta siswa untuk membuat kesimpulan.

\section{Hasil Observasi Keempat}

Observasi keempat dilakukan pada hari Selasa, 30 April di kelas X UPW A pada jam pelajaran 1-2, dengan materi yang disampaikan oleh guru yaitu Toshositsu de hon 0 yomimasu. Guru memulai pembelajaran dengan menampilkan sebuah gambar di LCD kemudian siswa disuruh mengamati gambar tersebut. kemudian siswa mengidentifikasi dan menebak arti dari kosa kata tersebut, guru mengucapkan contoh kosakata dalam bahasa Jepang. Siswa mengulang apa yang diucapkan guru sesuai dengan pelafalan dalam bahasa Jepang dan menerjemahkan ke dalam bahasa Indonesia.

Guru memberikan kesempatan kepada siswa untuk bertanya, pada observasi ini siswa bertanya terkait perbedaan ますdanません. Kemudian guru melakukan drill terhadap siswa dengan menampilkan gambar di powerpoint, siswa menyebutkan bahasa Jepang beserta artinya. Setelah kosakata disampaikan dengan baik, guru memberikan wacana, siswa diminta untuk menganalisis dengan baik wacana yang diberikan oleh guru, siswa berdiskusi untuk mencari pola kalimat serta makna dari wacana tersebut. Masing-masing kelompok menyebutkan pola kalimat dan menjelaskan maknanya. Guru kemudian 
menuliskan pola kalimat yang disebutkan siswa di papan tulis serta menjelaskan kembali jawaban dari siswa.

Siswa kemudian diarahkan untuk membuat contoh kalimat yang sesuai dengan pola kalimat yang sudah dipelajari. Siswa diperbolehkan untuk mencari informasi tambahan dari kamus, buku panduan maupun dari sumber lain. Siswa yang belum mendapat kesempatan untuk menyampaikan kalimat yang telah dibuat, ditunjuk untuk menebak makna dari kalimat yang telah disampaikan oleh siswa yang lain.

Selanjutnya siswa melakukan wawancara dengan teman sebangkunya. Siswa mengecek kembali dan membandingkan kosakata dan pola kalimat yang sudah dipelajari dengan hasil wawancara yang telah dibuat. Jika terdapat perbedaan, guru memperbolehkan siswa untuk bertanya dan berdiskusi dengan anggota kelompoknya. Wawancara dilakukan secara bergantian, apabila terdapat pola kalimat yang tidak sesuai diperbolehkan untuk mengangkat tangan dan memperbaiki pola kalimat yang salah. Selanjutnya sebelum mengakhiri kegiatan pembelajaran siswa diminta untuk melakukan refleksi pembelajaran.

\section{Hasil Observasi Kelima}

Observasi kelima dilakukan pada hari Selasa, 7 Mei 2019 di kelas X UPW A pada jam pelajaran 1-2, dengan materi yang disampaikan oleh guru yaitu "ikura desuka". Guru memulai dengan mengkaitkan materi sebelumnya dengan materi yang akan dipelajari. Guru menginstruksikan siswa untuk melihat dan mengamati gambar yang ada di powerpoint, kemudian siswa mengidentifikasi kosa kata yang diberikan oleh guru, guru mengucapkan contoh kosakata dalam bahasa Jepang siswa mengulang apa yang diucapkan guru sesuai dengan pelafalan yang benar dan menerjemahkan ke dalam bahasa Indonesia.

guru kemudian memberikan wacana bahasa Jepang, siswa diminta untuk menganalisis baik wacana tersebut. Siswa berdiskusi dengan kelompoknya untuk mencari pola kalimat serta makna dari wacana tersebut. Masing-masing kelompok menyebutkan pola kalimat dan menjelaskan makna yang mereka ketahui. Guru kemudian menuliskan pola kalimat yang disebutkan siswa di papan tulis serta menjelaskan kembali kepada siswa. Guru juga memberikan tambahan pengetahuan kepada siswa tentang tradisi budaya Jepang yang memberikan angpao yang dikenal dengan sebutan otoshidama「おとしだま. Guru kemudian memberikan kesempatan kepada siswa untuk bertanya terkait materi yang tidak dipahami Untuk mengetahui pemahaman siswa guru kemudian melakukan drill dengan menampilkan beberapa gambar di powerpoint, guru meminta dua orang siswa untuk melakukan tanya jawab dengan temannya sesuai dengan harga barang yang ditampilkan oleh guru.

Guru kemudian memberikan siswa kertas yang berisi nama barang dalam bahasa indonesia, kemudian menginstruksikan siswa untuk berdiskusi dengan anggota kelompoknya untuk membuat gambar daftar harga dan wacana yang sesuai dengan pola kalimat yang sudah dipelajari. Siswa dituntut agar mampu bekerja sama dengan team dan mampu beradaptasi dengan baik.

Siswa bersama kelompoknya diminta membuat gambar sekreatif dan sebagus mungkin beserta harga dari produk yang dibuatnya. Guru meminta beberapa kelompok yang ditunjuk secara acak untuk mempresentasikan hasil diskusinya. Kelompok lain menyimak dan membuat sebuah pertanyaan yang akan dilemparkan ke kelompok yang sudah menyampaikan hasil karyanya. Kelompok yang memperoleh poin paling banyak menjadi pemenang. Selanjutnya guru menginstruksikan siswa untuk melakukan refleksi kegiatan pembelajaran.

\section{Hasil Observasi Keenam}

Observasi terakhir dilakukan pada hari rabu, 8 Mei 2019 di kelas X UPW B pada jam pelajaran 1-2, dengan materi yang disampaikan oleh guru yaitu ikura desuka. Guru menginstruksikan siswa untuk melihat dan mengamati gambar yang ada di powerpoint, siswa kemudian mengidentifikasi kosa kata yang diberikan oleh guru, guru kemudian mengucapkan contoh kosakata dalam bahasa Jepang, siswa mengulang apa yang 
diucapkan guru sesuai dengan pelafalan dalam bahasa Jepang dan menerjemahkan ke dalam bahasa Indonesia.

Guru melakukan drill terhadap siswa dengan menampilkan gambar dan angka di powerpoint, siswa menyebutkan bahasa Jepang dan artinya. Kemudian guru memberikan kertas yang berisi wacana terkait materi pembelajaran. Selanjutnya meminta siswa berdiskusi dengan kelompoknya untuk mencari pola kalimat serta makna dari wacana tersebut. Masing-masing kelompok menyebutkan pola kalimat dan menjelaskan makna wacana tersebut. Guru kemudian menuliskan pola kalimat yang disebutkan siswa di papan tulis serta menjelaskan kembali kepada siswa. Guru juga memberikan tambahan pengetahuan kepada siswa tentang tradisi budaya Jepang yang memberikan angpao yang dikenal dengan sebutan otoshidama「おとしだま. Guru kemudian memberikan kesempatan kepada siswa untuk bertanya terkait materi yang belum dipahami. Siswa kemudian diarahkan untuk membuat contoh kalimat yang sesuai dengan pola kalimat yang sudah dipelajari, untuk mengetahui pemahaman siswa, kemudian guru meminta dua orang siswa untuk melakukan tanya jawab dengan temannya sesuai dengan harga barang yang ditampilkan oleh guru.

Guru kemudian memberikan siswa kertas yang berisi daftar harga dalam bahasa indonesia, siswa kemudian diarahkan untuk berdiskusi dengan anggota kelompoknya untuk membuat menu harga dan wacana yang sesuai dengan pola kalimat yang sudah dipelajari. Siswa bersama kelompoknya diminta membuat gambar sekreatif dan sebagus mungkin beserta harga dari produk yang dibuatnya. Setelah siswa selesai membuat menu harga, siswa membuat sebuah wacana singkat dalam bahasa Jepang berdasarkan gambar tersebut. Guru meminta beberapa kelompok yang ditunjuk secara acak untuk mempresentasikan wacana yang telah dibuat. Kelompok lain menyimak dan membuat sebuah pertanyaan yang akan dilemparkan ke kelompok lain. Kelompok yang memperoleh poin paling banyak menjadi pemenang. Selanjutnya guru menginstruksikan siswa untuk membuat kesimpulan terkait pola kalimat yang dipelajari.

\section{B. Pembahasan}

Pembelajaran berbasis $4 \mathrm{C}$ merupakan pembelajaran yang menuntut siswa memiliki kemampuan berpikir kritis dan pemecahan masalah (Critical-Thinking and Problem-Solving Skills), Kemampuan berkomunikasi (Communication Skills), Kemampuan bekerjasama (Collaboration Skills), Kemampuan mencipta dan membaharui (Creativity and Innovation Skills). Dalam penerapannya langkah-langkah pembelajaran berbasis 4C tidak dapat diklasifikasikan secara terpisah, karena pembelajaran 4C saling berhubungan dan berkaitan antara aspek yang satu dengan aspek yang lainnya.

Berdasarkan hasil observasi dan wawancara, penerapan pembelajaran bahasa Jepang berbasis 4C yang dilakukan oleh guru bahasa Jepang SMK Negeri 1 Singaraja adalah sebagai berikut.

Critical Thinking and Problem-Solving Kegiatan critical thinking and problem solving merupakan proses mental untuk menganalisis informasi yang didapatkan melalui suatu pengamatan untuk memeroleh pemecahan masalah. Triling dan Fadel (dalam Mukhlis, 2018) menyatakan bahwa keterampilan berpikir kritis mengacu pada kemampuan untuk menalar secara aktif, mengajukan pertanyaan dan memecahkan masalah, menganalisis dan mengevaluasi, serta melakukan refleksi proses pembelajaran dan keputusan.

Kecakapan berpikir kritis siswa dalam proses pembelajaran di lakukan dengan melakukan suatu pengamatan terkait materi pelajaran, guru menentukan objek yang akan diamati oleh siswa sesuai dengan materi pembelajaran, Guru memberikan kesempatan kepada siswa untuk mengidentifikasi pertanyaan sebanyak mungkin yang berkaitan dengan gambar atau ujaran yang disajikan dan dijawab melalui kegiatan pembelajaran. Siswa bertanya mengenai materi yang belum dipahami terkait penulisan huruf Jepang seperti penulisan「スポーツ」 “supootsu”「がっこう」“gakkou”, siswa juga bertanya perbedaan antara「ます」 “masu” dengan「ません」“masen”。 
Siswa juga mampu mengidentifikasi, mengolah, dan menganalisis informasi. Hal ini terlihat ketika guru membagikan sebuah wacana yang telah dibuat, siswa mendiskusikan dan mencari pola kalimat dan kosa kata yang terdapat dalam wacana serta makna dari wacana tersebut. Masing-masing kelompok kemudian mempresentasikan hasil diskusinya terkait isi wacana yang dibacanya. Guru memberikan kesempatan untuk menyampaikan persepsi atau tanggapan kepada siswa lain jika terdapat kesalahan.

Siswa diminta membandingkan pola kalimat dan makna kalimat dari bahasa Jepang ke bahasa Indonesia. Berdasarkan wawancara hal ini dilakukan guru agar siswa mengetahui konsep dan perbedaan pola kalimat antara bahasa ibu dan bahasa target.

Dalam kecakapan berpikir kritis siswa harus mampu menerapkan informasi yang sebelumnya sudah diperoleh melalui kegiatan analisis, dan mampu memahami konsep dari materi yang dipelajari, hal ini terlihat ketika siswa membuat sebuah kalimat yang sesuai dengan pola kalimat yang dipelajari, siswa kemudian diminta untuk membandingkan kalimat yang dibuat dengan kalimat yang dibuat oleh temannya

Siswa juga diarahkan untuk membuat wawancara, wacana atau karangan yang sesuai dengan pola kalimat. Hal ini terlihat pada observasi pertama dan kedua siswa membuat karangan tentang waktu yang diperlukan dalam melakukan kegiatan sehari-hari mulai dari pukul berapa bangun pagi, makan pagi, mandi, berangkat ke sekolah, pulang ke rumah, dan belajar. Siswa mengecek kembali dan membandingkan kosakata dan pola kalimat yang ada di buku.

Pada observasi kelima dan keenam, siswa diarahkan untuk membuat sebuah wacana dalam bahasa Jepang berdasarkan gambar sesuai dengan pola yang telah diajarkan. Kegiatan ini dilakukan berkelompok. Guru meminta kelompok lain menyimak dan mengidentifikasi hasil diskusi dengan membuat sebuah pertanyaan yang akan dilemparkan ke kelompok lain dan memberikan tanggapan jika terdapat kesalahan pada wacana yang disampaikan temannya. Siswa yang mampu mengoreksi hasil pekerjaan temannya akan mendapat tambahan nilai. Hal ini sesuai dengan kecakapan berpikir kritis dan pemecahan masalah yaitu mengidentifikasi, melakukan penilaian dan menentukan keputusan yang efektif terhadap informasi yang didapat (Ditjen, 2017).

Pada kegiatan ini siswa juga melakukan refleksi kegiatan dengan menyimpulkan materi pelajaran yang dibahas, guru tidak menjelaskan kosa kata atau ujaran, guru hanya meminta siswa untuk memikirkan jawaban dari pertanyaan yang diberikan guru. Hal ini terlihat ketika guru membuat kalimat yang rumpang kemudian siswa melengkapi kalimat yang rumpang sesuai dengan jawaban yang tepat. Selain itu siswa juga diminta untuk mencari perbedaan dan menyimpulkan fungsi dari setiap ujaran serta menyebutkan pola kalimat yang sebelumnya dipelajari.

Berdasarkan hal tersebut guru bahasa Jepang SMK Negeri 1 Singaraja sudah menerapkan aspek Critical-Thinking and Problem-Solving. Siswa mampu memahami materi pembelajaran, yaitu dengan cara melakukan pengamatan, mampu mengidentifikasi ujaran dari sudut pandang satu dengan sudut pandang yang lain, mampu mengolah dan menginterpretasi informasi yang diperoleh, mampu memahami interkoneksi antara satu konsep dengan konsep yang lain dalam suatu mata pelajaran, mampu menyusun, dan mengungkapkan, menganalisa dan menyelesaikan suatu masalah serta mampu merumuskan hasil diskusi yang dibuat dan mampu mengoreksi hasil pekerjaan teman lain jika terdapat suatu kesalahan.

\section{Collaboration}

Menurut Gokhale (2013) kegiatan collaboration mengacu pada proses pembelajaran dimana siswa dalam satu kelompok yang bervariasi tingkat kecakapannya bekerja sama dalam kelompok kecil yang mengarah pada tujuan bersama. Pada proses pembelajaran guru harus menciptakan situasi dimana peserta didik dapat belajar bersama-sama atau berkelompok (time work), sehingga akan tercipta suasana demokratis, dimana siswa dapat belajar saling menghargai perbedaan pendapat, menyadari kesalahan yang dibuat, serta dapat memupuk rasa tanggung jawab. 
Dalam kegiatan collaboration terlihat ketika guru menginstruksikan siswa mencari pasangan untuk melakukan percakapan. Siswa bekerja sama dengan pasangannya agar mampu melakukan percakapan dengan baik Kegiatan kolaborasi juga dapat dilakukan dengan membagi siswa menjadi beberapa kelompok yang terdiri dari 4-5 orang, di dalam kelompok terdiri dari siswa yang berbeda baik dalam gender, motivasi, kemampuan akademik dan personality. Guru akan memberikan masalah ataupun lembar jawaban yang harus dipecahkan bersama anggota kelompoknya.

Hal ini terlihat ketika siswa diberikan sebuah wacana, siswa kemudian mendiskusikan bersama kelompoknya untuk mencari pola kalimat dan mencari makna dari wacana tersebut. Selain itu siswa juga berdiskusi bersama kelompoknya dalam membuat karangan dan membuat wacana. Siswa melakukan diskusi dengan anggota kelompok untuk mencari solusi jika memiliki pendapat yang berbeda.

Hal ini sesuai dengan kecakapan yang harus ada dalam pembelajaran berbasis 4C dalam kegiatan collaboration yang menyatakan bahwa kecakapan terkait collaboration yaitu (1) kemampuan dalam kerjasama berkelompok, (2) Memiliki empati dan menghormati perspektif berbeda, (3) Mampu berkompromi dengan anggota yang lain dalam kelompok demi tercapainya tujuan yang telah ditetapkan (Ditjen, 2017).

\section{Creativity and Innovation}

Kegiatan creativity and innovation adalah keterampilan untuk memilih suatu tanggapan dan mampu mengemukakan kreatifitas. Mengemukakan kreatifitas adalah caracara berpikir yang divergen, berpikir yang produktif, berdaya cipta berpikir heuristik dan berpikir lateral. Dalam proses pembelajaran pendidik harus menciptakan kondisi dimana peserta didik harus dapat berkreasi dan berinovasi. Sehingga peserta didik dapat mengembangkan kreativitas yang dimilikinya untuk menghasilkan berbagai terobosan yang inovatif (Muslich, 2007:221).

Kegiatan Creativity \& Innovation terlihat ketika siswa diminta mampu menggunakan konsep-konsep atau pengetahuannya untuk membuat karangan dan wacana yang berkaitan dengan materi yang dipelajari. terlihat pada observasi pertama dan kedua siswa membuat karangan tentang waktu yang diperlukan dalam melakukan kegiatan sehari-hari mulai dari pukul berapa bangun pagi, makan pagi, mandi, berangkat ke sekolah, pulang ke rumah, dan belajar.

Pada observasi hari kelima dan keenam, siswa membuat karya berupa daftar harga dengan gambar sekreatif mungkin dan membuat wacana sesuai dengan daftar harga yang sudah dibuat. Siswa dituntut untuk mampu mengembangkan, dan menyampaikan gagasangagasan baru yang dimilikinya secara lisan atau tulisan. Pada observasi tersebut terlihat siswa tidak hanya menjelaskan tentang nama barang dan harga saja, melainkan beberapa siswa sudah mampu mengembangkan kreativitasnya dengan menjelaskan lebih rinci terkait barang tersebut seperti nama barang, harga barang, warna barang, kualitas barang dan tempat untuk membeli barang tersebut.

Siswa juga diberi kesempatan untuk menyampaikan kesimpulan terkait materi yang dipelajari dengan menggunakan bahasanya sendiri serta diberi kesempatan untuk menyampaikan pendapat dan saran tentang proses pembelajaran yang sudah berlangsung.

Berdasarkan hasil wawancara, tingkat kreativitas dan inovatif siswa di setiap kelas berbeda dari masing-masing siswa. Beberapa siswa sudah mampu mengembangkan gagasannya dengan membuat wacana lebih dalam terkait materi, namun beberapa siswa ada yang membuat wacana atau karangan hanya mengikuti contoh dengan mengganti objek, subjek, predikat dan keterangan.

\section{Communication}

Dalam kegiatan communication pembelajaran yang dilakukan oleh guru dan peserta didik harus terjadi komunikasi multi arah. Adanya komunikasi timbal balik antara guru dengan peserta didik, peserta didik dengan guru maupun antar peserta didik agar peserta didik dapat mengkonstruk pengetahuannya sendiri melalui komunikasi. 
Kegiatan communication terlihat dilaksanakan guru dan siswa dari awal proses pembelajaran sampai akhir proses pembelajaran. Guru dan siswa melakukan komunikasi secara intensif baik ketika guru menyampaikan materi maupun ketika siswa menebak kosa kata serta menjawab pertanyaan yang ajukan oleh guru.

Siswa juga diminta untuk melakukan kegiatan seperti membuat karangan, melakukan wawancara maupun berdiskusi tentang suatu topik dengan anggota kelompoknya. Setelah selesai, siswa atau anggota kelompok akan melaporkan hasil karangan, wawancara ataupun hasil diskusinya, sedangkan siswa yang belum mendapat giliran akan memperhatikan temannya dan diberikan kesempatan untuk mengoreksi hasil pekerjaan temannya jika terdapat kesalahan. Hal ini sesuai dengan teori yang menyatakan bahwa karakteristik kecakapan komunikasi dalam proses pembelajaran yaitu siswa mampu memahami, mengelola, dan menciptakan komunikasi yang efektif dalam berbagai bentuk dan isi secara lisan ataupun tulisan (Ditjen, 2017).

Guru akan memberikan apresiasi berupa acungan jempol, tepuk tangan, pujian dan nilai tambahan kepada siswa yang mampu mengoreksi kesalahan yang dilakukan oleh temannya. Menurut hasil wawancara dengan guru bahasa Jepang, siswa diharapkan mampu menciptakan komunikasi yang efektif baik secara lisan maupun tulisan.

Siswa juga mampu menggunakan bahasa lisan sesuai konten dan konteks pembicaraan. Hal ini melatih siswa berpendapat dan berbicara di depan umum. Kegiatan komunikasi yang dilakukan oleh guru telah berjalan sangat baik, siswa memperoleh informasi yang banyak dan mendapatkan pengetahuan tambahan melalui kegiatan wawancara yang dilakukan dengan teman yang lain maupun ketika berdiskusi ketika membuat wacana. Siswa lebih membuka wawasan dan dapat bertukar informasi dengan teman yang lain. pada kegiatan ini siswa dilatih untuk berkomunikasi dengan menggunakan bahasa Jepang agar siswa lebih lancar dalam berbicara menggunakan bahasa Jepang.

Penerapan pembelajaran bahasa Jepang berbasis 4C sudah dilaksanakan sesuai dengan tuntutan pembelajaran, tetapi terdapat kendala dalam menerapkan pembelajaran tersebut. Kendala yang dialami guru dalam menerapkan pembelajaran berbasis 4C yaitu kegiatan Creativity and Innovation dan kegiatan collaboration.

Kendala yang dialami guru dalam menerapkan pembelajaran berbasis $4 \mathrm{C}$ yaitu pada kegiatan Creativity and Innovation siswa kurang mampu menciptakan ide-ide dan gagasan baru serta mengembangkan kreativitas yang dimilikinya. Beberapa siswa ada yang membuat wacana atau karangan hanya mengikuti contoh dengan mengganti objek, subjek, predikat dan keterangan serta masih banyak siswa membuat karangan atau wacana dengan kalimat yang sebelumnya sudah dibuat.

Guru juga mengalami kendala dalam kegiatan collaboration Beberapa siswa ribut dengan topik pembicaraan lain dengan teman kelompoknya dan menggangu teman yang lain. Hal ini terlihat ketika siswa melakukan wawancara, latihan percakapan dan dalam kegiatan diskusi.

Selain itu guru juga mengalami kendala terkait alokasi waktu, waktu yang disediakan dalam pelaksanan pembelajaran bahasa Jepang di SMK Negeri 1 Singaraja dirasa kurang dalam melaksanakan keseluruhan pembelajaran.

Solusi yang diberikan guru untuk mengatasi kendala dalam kegiatan Creativity and Innovation dengan cara memberikan motivasi berupa penguatan verbal maupun non verbal dan arahan terhadap siswa untuk mengembangkan kreatifitas dan inovasinya meminta siswa mencari informasi tambahan dan membuat kalimat yang baru dengan mengubah subjek, keterangan, objek, dan keterangan yang berbeda dari yang sebelumnya dibuat oleh guru atau temannya. Guru juga meminta siswa untuk membuat projek sesuai dengan materi pembelajaran.

Solusi yang diberikan guru untuk mengatasi kendala dalam kegiatan collaboration dengan memberikan teguran kepada siswa tersebut, jika siswa masih ribut guru akan memperingati siswa dan memberikan sanksi yang tegas berupa pengurangan nilai.

Solusi yang dilakukan guru dalam mengatasi kekurangan waktu yaitu dengan memberikan materi-materi yang penting untuk diketahui siswa dan menginformasikan rencana kegiatan untuk pertemuan selanjutnya dan lebih disiplin dengan waktu. 


\section{Simpulan dan Saran}

Berdasarkan rumusan masalah, hasil penelitian, dan pembahasan maka dapat ditarik simpulan bahwa Implementasi pembelajaran bahasa Jepang berbasis 4C di SMK Negeri 1 Singaraja sudah dilaksanakan dengan baik. Namun pada kegiatan creativity and inovatif belum terlaksana dengan optimal, karena masih ada beberapa siswa kurang mampu menciptakan ide-ide dan gagasan baru serta mengembangkan kreativitas yang dimilikinya. serta pada kegiatan collaboration siswa menjadi ribut karena dituntut aktif dalam pembelajaran, disamping itu beberapa siswa ada yang membahas hal diluar konteks pembelajaran.

Guru juga mengalami kendala terkait alokasi waktu, waktu yang disediakan dirasa kurang dalam menerapkan keseluruhan pembelajaran.

Solusi yang diberikan guru untuk mengatasi kendala dalam menerapkan pembelajaran bahasa Jepang berbasis 4Cyaitu dengan memberikan motivasi berupa penguatan verbal maupun non verbal untuk meningkatkan kemampuan berpikir kreatif siswa serta meminta siswa untuk mencari informasi tambahan.

Untuk kendala dalam kegiatan collaboration guru mengatasinya dengan lebih sering berkeliling untuk melihat apakah siswa benar-benar membahas materi bersama kelompoknya, membimbing diskusi kelompok, dan memberikan teguran kepada siswa yang ribut.

Untuk mengatasi kendala terkait alokasi waktu guru akan menyampaikan kegiatan yang penting dan lebih mendisiplinkan waktu.

Berdasarkan temuan-temuan yang diperoleh dalam penelitian ini, saran yang dapat disampaikan yaitu guru diharapkan mampu menggunakan media pembelajaran yang tepat dan beragam seperti media pembelajaran powerpoint, LCD dan media lainnya agar siswa lebih termotivasi untuk belajar, dalam proses pembelajaran guru bisa memanfaatkan teknologi dengan mencari bahan materi di internet agar pembelajaran lebih bervariasi.

Untuk peneliti lain diharapkan dapat meneliti lebih dalam terkait implementasi pembelajaran berbasis $4 \mathrm{C}$ dalam pembelajaran bahasa Jepang seperti misalnya analisis keterampilan berpikir kitis dan pemecahan masalah pada pembelajaran bahasa Jepang.

\section{Daftar Pustaka}

Astawan, I Gede. 2017 "Belajar dan Pembelajaran Abad 21" Harian Bernas, Tersedia pada: http://www.pendidikan.id/4907-belajar-dan-pembelajaran-abad-21 (diakses pada tanggal 30 oktober 2018)

BSNP. 2010. Paradigma Pendidikan Nasional Abad XXI. [Online]. Tersedia pada:http://www.bsnpindonesia.org/id/wp-content/uploads/2012/04/Laporan-BSNP_2010.pdf.. (diakses pada tanggal 30oktober 2018)

Ditjen. 2017. Implementasi Pengembangan Kecakapan Abad 21 Dalam Perencanaan Pelaksanaan Pembelajaran (Rpp). Tersedia pada http://www.berkasedukasi.com. (diakses pada tanggal 11 november 2018)

Diantari, Ni Putu Indah, dkk. 2017. Implementasi Pembelajaran dengan Pendekatan Saintifik oleh Guru Bahasa Jepang di SMA Pariwisata Saraswati Klungkung. Skripsi . Undiksha. Tersedia pada https://ejournal.undiksha.ac.id/index.php/JJPBJ/article/view/13315

Ghazali, Syukur. 2010. Pembelajaran Keterampilan Berbahasa dengan Pendekatan Komunikatif-Interaktif. Jakarta : PT. Retika Aditama.

Hossoubah. 2007) .Developing Creative and Critical Thinking Skills (terjemahan). Bandung: Yayasan Nuansa Cendia. Tersedia pada http://repository.upi.edu/6467/9/S SEJ 0901687 Bibliography.pdf

Lunenburg, Fred C, 2011. "Critical Thinking and Constructivism Techniques for Improving Student Aachievement." National Forum of Teacher Education. Journal. Vol. 21. No. 3.

Mukhlis, Muhammad, dkk. 2018. Analisis Kemampuan Berpikir Kritis Siswa Dalam Menyelesaikan Deret Aritmatika Dimensi Dua Berdasarkan Keterampilan 4C-P21. Tesis (tidak diterbitkan). Program Magister Pendidikan Matematika Fakultas Keguruan dan 
JPBJ, Vol. 5 No. 2, Juli, 2019

ISSN: 2613-9618 $\begin{array}{llll}\text { Ilmu Pendidikan.Universitas } & \text { Jember. } & \text { Tersedia } & \text { pada } \\ \text { http://repository.unej.ac.id/handle/123456789/88121 } & & \end{array}$

Singaraja. 